Relations industrielles

Industrial Relations

\title{
Statics and Dynamics of Inflation
}

\section{E.F. Beach}

Volume 31, numéro 4, 1976

URI : https://id.erudit.org/iderudit/028750ar

DOI : https://doi.org/10.7202/028750ar

Aller au sommaire du numéro

\section{Éditeur(s)}

Département des relations industrielles de l'Université Laval

\section{ISSN}

0034-379X (imprimé)

1703-8138 (numérique)

Découvrir la revue

\section{Citer cet article}

Beach, E. (1976). Statics and Dynamics of Inflation. Relations industrielles /

Industrial Relations, 31(4), 676-681. https://doi.org/10.7202/028750ar

Tous droits réservés (C Département des relations industrielles de l'Université Laval, 1976
Ce document est protégé par la loi sur le droit d'auteur. L'utilisation des services d'Érudit (y compris la reproduction) est assujettie à sa politique d'utilisation que vous pouvez consulter en ligne.

https://apropos.erudit.org/fr/usagers/politique-dutilisation/ 
«coût de la vie» des mesures Trudeau protège correctement contre l'inflation, si on ne considère que son aspect indexation ${ }^{10}$. Mais la même composante constitue une sur-protection, si l'on ne retient que son aspect montant forfaitaire. La même démonstration que celle de la section précédente peut être utilisée ici. Ainsi, en supposant que l'inflation de la première année ait cru régulièrement chaque mois au taux annuel de $8 \%$, la forme «montant forfaitaire» de la protection contre l'inflation des mesures Trudeau n'aurait dû atteindre approximativement que $4.3 \%^{11}$, au lieu de $8 \%$.

\section{CONCLUSION}

Le présent texte visait à démontrer que la protection des salaires contre l'inflation peut se faire de trois (3) façons différentes. Nous avons expliqué chacune de celles-ci, en faisant soigneusement ressortir les différences essentielles entre elles. La composante «coût de la vie» constitue en fait une indexation avant coup des salaires sur un indice des prix, par exemple l'I.P.C. Cette indexation procure une certaine compensation pour la perte de pouvoir d'achat des salaires, au cours de la période courante, et rehausse en même temps le taux de salaire en prévision de l'inflation de la même période. Si, par contre, l'indexation des salaires ne se fait qu'en fin de période (au début de la période suivante), cette forme de protection à elle seule ne protège pas contre la perte de pouvoir d'achat des salaires de la période qui se termine. C'est alors que la troisième forme de protection entre en ligne de compte, soit le montant forfaitaire. Puis, ces trois formes de protection sont étudiées dans les conventions collectives du secteur public et parapublic de 1972 à 1975. Cette étude nous a permis de conclure que les montants forfaitaires qui y ont été versés ont été presque deux fois trop élevés, comparativement aux montants requis pour une pleine compensation. Dans la même veine, il est apparu que les mesures Trudeau comprenaient, implicitement dans la composante "coût de la vie», des montants forfaitaires également presque deux fois trop élevés.

\section{STATICS AND DYNAMICS OF INNOVATION}

\section{E. F. Beach *}

It has long been agreed that if the demand for a commodity is elastic, the reduction in labour requirements through technological change will be offset enough to maintain the workers in employment.

10 À condition, bien entendu, que l'inflation réelle de l'année courante ne soit inférieure au taux prévu au début de l'année.

$114.3 \%$ = la somme divisée par 12 des pourcentages excédentaires mensuels.

* BEACH, E. F., Professor, Department of Economics, Mc Gill University, Montreal. 
We shall show this to be doubtful theoretical analysis, and suggest the need of an alternative approach to explain the increase in employment that have characterised past economic growth. Fortunately, a more adequate one does exist.

In 1757 Josiah Tucker argued that the expansion in demand which results from the reduction in price could induce much increase in employment. ${ }^{1}$ This idea has persisted, now expressed in the jargon of price elasticity of demand. ${ }^{2}$ follows :

Consider a simple version of an income statement of a firm as

$$
\mathrm{S}=\mathrm{M}+\mathrm{F}
$$

where $S=$ total annual sales in dollars, $M=$ the payment for materials and supplies, and $F=$ payment for factor services. $F$ can be further specified as the sum of $\mathrm{W}=$ the annual wage bill, and $\mathrm{K}=$ the gross return to capital, including $\mathrm{D}$, the allowance for depreciation, and $\mathrm{N}$, the net return, which may be in part payment for interest, and in part a payment for profits.

Let us assume that a process innovation is made, lessening the unit cost and hence the price, p. Output will tend to increase, but $S$ will increase only if demand is elastic. If $M=O$, then the total payment for factor services will change in the same way as S. If, then, technological change increases $\mathrm{K}$ at the expense of $\mathrm{W}$, the latter will be maintained only if $\mathrm{S}$ increases faster than $\mathrm{K}$. Thus, the elasticity of demand must be greater than unity (numerically), and sufficiently large to offset the increase in annual capital costs (including profits).

It is conceivable that $\mathrm{K}$ could decrease. This could happen if a plant is fully depreciated and replaced by one which costs less and yet requires less labour to operate it. The term «operate» is to be taken in a broad sense so as to include any labour added elsewhere, such as at the head office, as a result of the change in the plant. It seems more usual, however, that a reduction in operating labour entail some increase in capital. ${ }^{3}$ Sometimes a part of the extra investment is hidden elsewhere in the company accounts, written off as current expense ${ }^{4}$, or left on someone else's shoulders. ${ }^{5}$

1 TUCKER (1957), p. 21.

2 BROZEN (1957) \& (1959).

3 HARWELL gives a wealth of data on the cement industry, showing rapid technological change, and rapid obsolescence. He saw difficulty in obtaining the required capital to rehabilitate the industry. BROZEN (1959) gives a number of examples of new investment needed.

4 Research laboratories operated by industry are characteristically regarded as part of ordinary expense, thus implying that when a new automobile is purchased, a part of the price goes for the improvement of future automobiles.

5 Consideration should be given to unsuccessful attempts at innovation, when considering the dynamics of the whole macro process. Investment therefore increases incomes and employment, and some vestige of benefit may well result in other ways. Mr. Zeckendorf went bankrupt in the course of rebuilding Montreal's Dorchester Street, but the benefits to the city have been immense. 
When $\mathbf{M}$ is taken to be zero, all of the costs are factor payments, and the firm (or industry) is said to be fully integrated. ${ }^{6}$ Such a situation is not a realistic one. Consider, then that $\mathbf{M}=\mathrm{mq}$, where $\mathrm{q}$ is the quantity of output, and $\mathrm{m}$ is the cost of materials and supplies per unit of output. Let us assume for the moment that $\mathrm{m}$ is constant, so that $\mathrm{M}$ increases in proportion to $\mathrm{q}$ when $\mathrm{p}$ falls. $\mathrm{S}$ on the other hand, will increase only if the demand is elastic. If $\mathrm{m}$ is a small fraction of $p$ at the start, then $F$ can increase for a while, when $S$ expands, but $M$ will eventually catch up, and thereafter, $F$ must fall with each increase in output. We assume that the demand is not infinitely elastic.

The difficulty of maintaining $\mathrm{W}$ is now much greater. The elasticicity must be not just greater than unity, to allow $S$ to increase, but even greater, so that $\mathrm{F}$ can increase, so as to allow $\mathrm{K}$ to increase relative to $\mathrm{W}$. If the demand curve is not to become very flat indeed, this becomes increasingly difficult as q increases. The scope depends, also, on the value of $m$.

It seems clear that in general, the value of the elasticity of clemand must be greater than what can be expected for many commodities that have been affected by technological change. The analysis must be broadened. One assumption that should be removed is the constancy of $\mathrm{m}$. With the expansion of an industry, there will be economies in the production of more materials and supplies, though these economies can be offset by diseconomies. Here is an area for Schumpeter's «linked» innovations, and the history of the textile industry illustrates it. Innovations in weaving, spinning, and preparing the fibre were interrelated.

But relying on further technological change is only to increase the scope for labour displacement. This cannot be the answer we seek. Some theorists find the answer in the indirect employment that is entailed in the making of the machines. Most of these theorists limit themselves however, to that employment that is implied in the replacement, i.e., in the depreciation allowances. It has been shown that this static argument is inadequate. ${ }^{8}$

The really significant lesson to be learned from this exercise is that all of these analyses are static approaches, and something more is needed by way of dynamics in order to find the answer to the question, that is the explanation of how employment increases. We must

6 See, for example, PIGOU (1920) Part IV, Chapter IV; and NEISSER (1942) p. 56 .

7 See Appendix. The 1974 Canada Year Book tells us (p. 664) that for the year 1971, value added in manufacturing as a whole was somewhat less than one half. Taking $\mathrm{m} / \mathrm{p}$ to be one-half, quick calculations suggest that the price elasticity of demand cannot be less than two if $F$ is to be allowed to expand as $p$ falls.

8 BEACH (1974). GREGORY (1930) cites Chalmers as presenting this view, presumably in 1832 . 
understand the process of innovation, and why a change results in growth. ${ }^{9}$

The dynamics that is relevant can be illustrated by theoretical developments in international adjustments. Taussig ${ }^{10}$ was wedded to the classical explanation of adjustments being based on gold flows, and yet he noticed that actual adjustments seem to happen without such flows. Shortly thereafter the discussion of the reparations question disclosed that there were other active ingredients, in particular movements in income that happened rather more directly than through gold flows. These income effects became a part of accepted analysis as can be seen from texts such as that of Haberler (1937) and Marsh (1951). ${ }^{12}$ Keynes, of course, made much more extensive use of income effects in his GENERAL THEORY.

A similar change should take place in theorizing about innovations. There are income effects, and they are powerful. They arise from the new investment, they begin early, and can certainly help to explain the way in which growth develops out of changes in the production process. ${ }^{13}$ The power of the income effects arises from the fact that the amount of the new investment is a multiple of the annual saving in the wage bill. Indeed, a multiplier can be attached to the investment, when new money is involved.

The difference between static and dynamic theorizing can be shown in another way. Those who have used the "elasticity of demand" argument have usually been silent on the cases when the demand is inelastic, though sometimes refuge is taken in the idea that long run elasticities tend to be greater than short run elasticities because it takes time to adjust mentally and physically to changes. There are some, however, ${ }^{14}$ who see inelastic demand as no impediment because any loss in expenditures from the commodity under discussion is seen as a gain in expenditures for others, assuming that there is maintenance spending power. But maintenance of such purchasing power is felt to be not enough if $\mathrm{K}$ expands. There is another roadblock used, for example by Neisser. ${ }^{15} \mathrm{He}$ argues that if the shift in purchasing power is

9 M. Yves DUBÉ pointed out some years ago that the title of my first paper in this journal (1967) should have the work «l'automatisation» in the title, rather than "l'automation». The English language is not so flexible, and I did not then realize the full value of his suggestion.

10 See TAUSSIG (1927), pp. 298-9.

11 Ellis and Metzler (1950) reprints three articles by KEYNES, OHLIN, and METZLER. The one by Ohlin, which appeared first in the ECONOMIC JOURNAL in June 1929 was perhaps the most significant.

12 HABERLER, pp. 51-3 and MARSH, pp. 218-26.

13 This discussion is in terms of process innovation, but the theory is essentially the same for product innovation, market expansion and other types, when additional new investment is an important early feature, with subsequent adjustments. See BEACH (1967) and (1971).

14 DOUGLAS and Director (1931) and NEISSER (1942).

15 NEISSER (1942) pp. 55,6. See also BROZEN (1957). 
towards commodities that are capital intensive, there will be a loss in employment. The shift in demand to electrical power would be a case in point. Suppose, however, that such a shift continues; there would certainly be pressure to increase capacity of this industry, and we are once more in a position to introduce the income effects that arise from such expansion, as above. Thus, through the effects of the new investment, total expenditures could increase, even though there is excess capacity somewhere in the economy. These «short run» investment effects continue for long periods if the investment continues.

Fellner ${ }^{16}$ has defended neoclassical models by claiming that they do their job and are not misleading. We suggest that the static theorizing characteristic of analyses of innovation is misleading. The equilibrium approach is based on the technique of partial equilibrium theorizing in which a shift in a production function produces a new equilibrium, and the comparison of the two equilibrium gives no consideration to the process of moving from the one point to the other. Any investment that was entailed has vanished from the scene. This analysis is generalized by simple aggregation ${ }^{17}$ and sometimes a so-called dynamic equilibrium is conceived of such equilibrium points moving through time. The result is a distortion of actual change in which investment is a continuing feature. If the pace of change is speeded up, the amount of investment is increased. To ignore it is to produce distortion.

\section{APPENDIX}

Factor Payment: $\mathrm{F}=\mathrm{S}-\mathrm{M}=(\mathrm{p}-\mathrm{m}) \mathrm{q}$

Assume a linear demand curve: $\mathrm{p}=\mathrm{a}-\mathrm{bq}$

The derivative of $F$ with respect to $q$ is: $(a-m)-2 b q$, which is positive only so long as $a$ is greater than the other two elements. A demand curve of constant elasticity 18 can be expressed as $p q^{\bar{n}}=c$. The derivative of $F$ w.r.t. $q$ is $c q^{-n}(1-n)^{-m}$ which is positive only when $n$ is negative, which is true for an elastic curve, and when the first term exceeds the second. It should benoted that the first term decreases continually with an increase in $\mathrm{q}$. Thus eventually the derivative becomes negative, and $\mathrm{F}$ must shrink.

If the demand curve could be expressed as $(p-m) q^{n}=c$, the derivative becomes $c(1-n) q^{-\bar{n}}$ which is always positive for elastic curves, but decreases con-

16 FELLNER (1970) p. 2:

«Objections raised against the neoclassical models are quite inconclusive in their present form, because the question is not whether the assumptions underlying such models are «realistic» (a good photograph of reality), but whether in the real work these assumptions are violated in such respects and to such an extent as to render the analytical results misleading. This the critics have so far not even tried to show.» The italics are in the original.

17 See BEACH (1975).

18 See ARCHIBALD and LIPSEY, p. 127. 
tinuously. Even here, the scope for $\mathrm{K}$ to expand at the expense of $\mathrm{W}$ decreases as $\mathrm{q}$ increases.

These relations can be shown with simple diagrams. Alternatively they may be expressed in terms of the elasticity of demand. The rate of change of $S$ w.r.t. price is $(e+1) q$, and the rate of change of $F$ w.r.t. $p$ is $(e+1) q-m$. Thus, $S$ increases when the demand is elastic, but an increase in $F$ requires a greater elasticity of demand, depending upon the size of $\mathrm{m}$.

\section{REFERENCES}

Abbreviations: l'A.E. l'actualité économique

A.E.R. American economic review

E.J. Economic journal

I.R.I. Industrial relations industrielles

ARCHIBALD, G. C. and LIPSEY, R. G., An introduction to a Mathematical Treatment of Economics, London, 1967.

BEACH, E. F., «La théorie économique de l'automation» IRI, 1967.

BEACH, E. F., «A Naive Argument», IRI, August 1974.

BEACH, E. F., «Marxian Analysis», IRI, 1975.

BEACH, E. F., «La mécanisation et l'emploi », L'Actualité économique juillet-septembre, 1971.

BROZEN, Y., "The Economics of Automation», A.E.R., May 1957.

BROZEN, Y., "Automation's Impact on Capital and Labor Markets» in H. B. Jacobson \& J. S. Roucek, Automation and Society, N.Y., 1959.

\section{CANADA YEARBOOK.}

DOUGLAS, P. H. \& A. Director, The Problem of Unemployment, N.Y. 1931.

ELLIS, H. S. \& L. A. METZLER, Readings in the Theory of International Trade, Phila. 1950.

FELLNER, W., "Trends in the Activities Generating Technological Progress» A.E.R., March 1970.

GREGORY, T. E., «Rationalization and Technological Unemployment» E. J., December 1930.

HABERLER, G. von, The Theory of international Trade, N.Y. 1937.

HARWELL, R. S., «For the Cement Industry: A Time of Crisis», Rock Products, April and May, 1968.

MARSH, D. B., World Trade and Investment, N.Y. 1951.

NEISSER, H. P., “'Permanent' Technological Unemployment», A.E.R., March 1942.

OHLIN, B., "The Reparation Problem: A Discussion: I. Transfer Difficulties, Real and Imagined», E. J. June, 1929.

PIGOU, A. C., The Economics of Welfare, London, 1920.

TAUSSIG, F. W., International Trade, N.Y. 1927.

TUCKER, J., Instructions for Travelers, London, 1757. 